\title{
Chloropicrin as a soil fumigant in forest nurseries
}

\author{
by David B. South, William A. Carey and Scott A. Enebak
}

Chloropicrin has been tested as a soil fumigant in forest nurseries throughout the world. From 1944 to the late 1960 's, tests were conducted in Australia, Canada, Netherlands, New Zealand, the United Kingdom and the United States. Since 1985, studies have been conducted in Georgia, Mississippi, South Carolina, Texas, Virginia, Washington and Wisconsin. In Wisconsin, chloropicrin reduced soilborne pathogens as effectively as twice as much methyl bromide. Advantages of chloropicrin as a soil fumigant in southern pine nurseries include: efficacy similar to methyl bromide (in regards to reduction in fungi, nematodes and insects), an increase in Trichoderma populations, it is not a Class 1 ozone depleting substance, and no plastic tarp is required. Adding chloropicrin to other fumigants has increased the spectrum of biological activity. A disadvantage of chloropicrin is that it has less herbicidal activity than methyl bromide.

Key words: fungicide, methyl bromide, disease, nursery management, seedbeds
La chloropicrine a été testé en tant que fumigène des sols dans les pépinières forestières de tous les pays. De 1944 à la fin des années 60, des essais ont été entrepris en Australie, au Canada, aux Pays-Bas, en Nouvelle-Zélande, au Royaume-Uni et aux ÉtatsUnis. Depuis 1985, des études ont été réalisées en Géorgie, au Mississippi, en Caroline du Sud, au Texas, en Virginie, dans l'Etat de Washington et au Wisconsin. Au Wisconsin, la chloropicrine a réduit les pathogènes pédologiques aussi efficacement que deux fois le niveau atteint avec le bromure de méthyle. Les avantages de la chloropicrine en tant que fumigène des sols pour les pépinières de pin du sud comprennent: une efficacité semblable au bromure de méthyle (par rapport à la réduction des champignons, des nématodes et des insectes), une augmentation des populations de Trichoderma, il ne s'agit pas d'une substance dégradant l'ozone de classe 1 , et elle ne nécessite pas de toile de plastique. L'addition de la chloropicrine aux autres fumigènes a augmenté le registre d'activité biologique. Un désavantage de la chloropicrine réside dans une action phytocide moindre que le bromure de méthyle.

Mots clés: fongicide, bromure de méthyle, maladie, gestion de pépinière, planches d'ensemencement

\section{Introduction}

Chloropicrin has a specific gravity of 1.66 and a vapor pressure of $18.3 \mathrm{~mm} \mathrm{Hg}\left(\right.$ at $\left.20^{\circ} \mathrm{C}\right)$. It is a colorless liquid with an intensely irritating odor, commonly known as tear gas and is a restricted use pesticide. The boiling point $\left(112.4^{\circ} \mathrm{C}\right)$ is higher than water and the gas is about 5.7 times heavier than air (Sassaman et al. 1986). It is slightly soluble in water (2,000 ppm). On a weight basis, chloropicrin is the second most commonly used fumigant in forest nurseries in the United States. In the southern states, more than 20 tonnes of chloropicrin are used annually to produce one billion pine seedlings. Currently, chloropicrin is added to methyl bromide as a warning agent to enhance safety or it is added to enhance fungicidal efficacy (e.g. $33 \%$ chloropicrin and $67 \%$ methyl bromide). It is also used in combination with other fumigants such as 1,3-dichloropropene. Even when used as the only active ingredient, chloropicrin can be an effective soil fumigant (Jackson 1934; Stark 1948).

\section{Early Nursery Trials}

Chloropicrin has been tested in forest nurseries throughout the world. In 1944, a test was conducted in a nursery in the state of Washington (Breakey et al. 1945). Douglas-fir (Pseudotsuga menziesii Mirb.) seedbeds containing seed-corn maggots (Hylemyia cilicrura) were fumigated in mid June. Seed were sown a week later on June 25 . At time of sowing, "the fumes of chloropicrin were still coming from the soil in appreciable amounts..." Chloropicrin reduced injury from the seed-corn maggot and "the bed which had been treated with chloropicrin

School of Forestry and Alabama Agricultural Experiment Station, Auburn University, AL 36849-5418, USA was outstanding in the uniformity and vigor of the young fir seedlings."

In 1947, seedbeds of longleaf pine (Pinus palustris Mill.) and slash pine (Pinus elliottii Engelm.) were treated in Mississippi (Lindgren and Henry 1949). Seeds were sown on March 18, at least two weeks after treatment. Chloropicrin (644 $\mathrm{kg} \mathrm{ha}^{-1}$ ) was outstandingly successful in controlling a root disease which may have resulted from injury due to nematodes (Table 1).

During the 1950s and 1960s, tests were conducted in the United Kingdom (Benzian 1959, 1965; Aldhous 1972), Australia (Brown 1985), Neatherlands (Pouwer and van Doesburg 1967), New Zealand (Thulin et al. 1958; Will and Bassett 1959; Will 1962; Bassett and Will 1964), Canada (van den Driessche 1963a,b; 1969; Agnihotri 1971), Japan (Terashita 1962), Germany (Ruhm 1959) and the United States (Coz 1951; White and Potter 1963). The following synopsis of chloropicrin is paraphrased from van den Driessche (1969).

Chloropicrin is an effective fungicide, has nematocidal properties, and reduces weed growth. Douglas-fir responds well on soils treated with chloropicrin (Will 1962; Thulin et al. 1958; van den Driessche 1963a, 1968). Chloropicrin may be either injected to a depth of $15 \mathrm{~cm}$ or chiseled into the soil at a rate of $336 \mathrm{~kg} \mathrm{ha}^{-1}$. Chloropicrin applied at 168 $\mathrm{kg} \mathrm{ha}^{-1}$ in two coastal nurseries markedly improved growth of Douglas-fir, and $84 \mathrm{~kg} \mathrm{ha}^{-1}$ caused some positive response (van den Driessche 1963b).

Both soil temperature and soil moisture influence the effectiveness of chloropicrin. Soil moisture content of 1 to $15 \%$ is optimum and, though soil temperatures around $20^{\circ} \mathrm{C}$ are desirable, satisfactory results were obtained with soil temperatures 
Table 1. Effect of $644 \mathrm{~kg} \mathrm{ha}^{-1}$ of chloropicrin on seedling production at the Ashe Nursery in 1947.

\begin{tabular}{|c|c|c|c|c|c|c|}
\hline \multirow[b]{2}{*}{ Treatment } & \multicolumn{2}{|c|}{ Total seedlings $\mathrm{m}^{-2}$} & \multicolumn{2}{|c|}{ Plantable seedlings $\mathrm{m}^{-2}$} & \multicolumn{2}{|c|}{ "Healthy" plantable seedlings $\mathrm{m}^{-2}$} \\
\hline & Longleaf & Slash & Longleaf & Slash & Longleaf & Slash \\
\hline Chloropicrin & 106 & 360 & 102 & 300 & 70 & 236 \\
\hline Untreated & 69 & 397 & 62 & 309 & 0 & 109 \\
\hline
\end{tabular}

varying from 2 to $20^{\circ} \mathrm{C}$ (Benzian 1965). Chloropicrin deteriorates with storage and good results can only be obtained with fresh material.

Aldhous (1972) summarized some early fumigation trials from 14 nurseries in Scotland and England. In February or March, chloropicrin $\left(664 \mathrm{~kg} \mathrm{ha}^{-1}\right)$ was injected into the soil at least three weeks before sowing. Sitka spruce (Picea stichensis Bong. Carrière) growing in chloropicrin plots were significantly taller in $69 \%$ of the trials. In some 86 trials (which included trials with four other conifers), a significant decrease in seedling production occurred in only 6 trials. Several of the negative responses were from one silt-loam nursery. Aldhous indicated that a three week interval may not be sufficient where fine textured soils remain wet or at nurseries with poor drainage. He suggested that chloropicrin might be hazardous to seedlings if the soil remains wet for a considerable period of time after treatment. Seedling height increased only $50 \%$ of the time on fine textured soils. He indicated that on "light to medium loam" soils, the growth gains from fumigation with chloropicrin could shorten the nursery phase by one year.

\section{Recent Nursery Trials}

For about two decades (1965-1985) there were few trials with $100 \%$ chloropicrin in forest nurseries. Combinations of methyl-bromide and chloropicrin were tested and these mixtures soon became the industry standard. Interest in chloropicrin has recently increased because the production of methylbromide in the United States might cease after the year 2001. Trials with $100 \%$ chloropicrin have been conducted in Wisconsin (Enebak et al. 1990), Washington (Stevens 1997) as well as in the southern United States (Carey 1994). The following provides some highlights of this research.

Since 1990, the Auburn University Southern Forest Nursery Management Cooperative has conducted fumigation trials in Georgia, Mississippi, South Carolina, Texas, and Virginia. Some studies included chloropicrin at rates from 140 to $392 \mathrm{~kg} \mathrm{ha}^{-1}$. Most of the chloropicrin treatments were applied without polyethylene tarps. In no Cooperative study did chloropicrin cause a significant reduction in either size or number of seedlings. Increases in number of seedlings produced occurred in pathogen infested soil in Wisconsin, but thus far, no large increases have occurred in southern nurseries (Table 2). This is possibly due to reduced disease pressure as a result of prior fumigations (Last and Cole 1969).

\section{Effects on Soil Pathogens and Nematodes}

Overall, chloropicrin is a better fungicide than methyl bromide. Some believe $1 \mathrm{~kg}$ of chloropicrin is as effective as 2 $\mathrm{kg}$ of methyl bromide (Table 3 ). This view is consistent with results from a white pine (Pinus strobus L.) study in Wisconsin. Chloropicrin at $196 \mathrm{~kg} \mathrm{ha}^{-1}$ was as effective as methyl bromide at $392 \mathrm{~kg} \mathrm{ha}^{-1}$ in reducing soilborne Fusarium, Rhizoctonia and Pythium (Enebak et al. 1990). Chloropicrin is also an effective nematicide (Stark 1948; Benzian 1965) and, on an equiv- alent weight basis, is as effective on nematodes as methyl bromide (Table 3). In one test, chloropicrin at $249 \mathrm{~kg} \mathrm{ha}^{-1}$ reduced nematodes by $80 \%$ while methyl bromide at $450 \mathrm{~kg}$ $\mathrm{ha}^{-1}$ resulted in a $94 \%$ reduction (Harris 1991).

\section{Effects on Weeds}

Methyl bromide is more effective as a herbicide than chloropicrin. In particular, methyl bromide is better for suppressing yellow nutsedge (Cyperus esculentus) and purple nutsedge (Cyperus rotundus). In general, it takes two and a half times more chloropicrin to equal the weed control effectiveness of methyl bromide (Table 3). This suggests that $1125 \mathrm{~kg}$ $\mathrm{ha}^{-1}$ of chloropicrin might be as effective as $450 \mathrm{~kg} \mathrm{ha}^{-1}$ of methyl bromide (the cost of this amount of chloropicrin would approach $\$ 8,800 \mathrm{ha}^{-1}$ ). Although chloropicrin has some herbicidal activity (Harris 1991), it will likely not be used for weed control in southern forest tree nurseries. Effective herbicides are currently available for conifers, and if applied appropriately, will be more cost effective than fumigation (McNabb et al. 1995).

Some managers of hardwood nurseries currently use on methyl bromide for both weed control and disease suppression. If these managers decide to fumigate with chloropicrin instead of methyl bromide, they will need to increase their emphasis on weed management. Some may decide to increase the use of herbicides while other managers may choose to employ more handweeding labor (South 1995).

\section{Effects on Hardwoods}

Several soil fumigation trials with chloropicrin increased growth of pear (Pyrus spp.), apple (Malus spp.) and citrus (Citrus spp.) (Mai and Abawi 1978; Sewell et al. 1992). In one

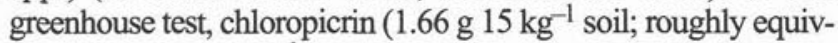
alent to $220 \mathrm{~kg} \mathrm{ha}^{-1}$ ) increased growth of pear and apple seedlings in 14 out of 19 orchard soils (Koch et al. 1980). However, stunting of hardwood seedlings can occur on nurseries with fine textured soils. For example, on a clay soil chloropicrin $\left(581 \mathrm{~kg} \mathrm{ha}^{-1}\right)$ reduced height growth of several hardwood species (Pouwer and van Doesburg 1967). In England, chloropicrin at $332 \mathrm{~kg} \mathrm{ha}^{-1}$ has been applied in the fall one month before sowing large-seeded hardwoods (Hipps et al. 1997). In the United States, several forest nursery managers have grown hardwoods after treating soil with a combination of chloropicrin and 1,3-dichloropropene. At one nursery in Georgia, seedbeds treated with $80 \mathrm{~kg} \mathrm{ha}^{-1}$ of chloropicrin (mixed with $394 \mathrm{~kg} \mathrm{ha}^{-1}$ of 1,3-dichloropropene) produced plantable seedlings of sycamore (Platanus occidentalis) and sweetgum (Liquidambar styraciflua L.) (South 1977).

\section{Effects on Mycorrhizae}

The effects of chloropicrin on ectomycorrhiza of white pine (Pinus strobus L.) were reported by Enebak and others (1990). There was no evidence that chloropicrin applied under a tarp $\left(196 \mathrm{~kg} \mathrm{ha}^{-1}\right)$ adversely affected mycorrhizal colonization. In 
Table 2. Effects of chloropicrin fumigation on pine seedling production and size (relative to untreated soil).

\begin{tabular}{|c|c|c|c|c|c|c|c|}
\hline Location & State & Year & $\begin{array}{c}\text { Rate } \\
\mathrm{kg} \mathrm{ha}^{-1}\end{array}$ & Treatment date & Sowing date & $\begin{array}{l}\text { Seedling } \\
\text { numbers }\end{array}$ & Seedling size \\
\hline Boscobel & WI & 1986 & 196 & September 4 & October 19 & Increase & Increase \\
\hline Statesboro & GA & 1993 & 280 & October 21 & May 14 & Same & Same \\
\hline Summerville & $\mathrm{SC}$ & 1993 & 280 & March 18 & April 14 & Same & Increase \\
\hline Olympia & WA & 1993 & 224 & July 30 & May 3 & Decrease & Increase \\
\hline New Kent & VA & 1994 & 336 & April 14 & May 3 & Same & Increase \\
\hline Winona & MS & 1994 & 278 & April 27 & May 18 & Same & Same \\
\hline Glennville & GA & 1996 & 392 & February 16 & April 10 & Same & Increase \\
\hline Texas & TX & 1996 & 392 & March 23 & April 16 & Same & Increase \\
\hline
\end{tabular}

fact, on one sampling date (13 August, 1987) seedlings from the chloropicrin treatment had almost twice the mycorrhizal colonization of seedlings growing in nonfumigated soil. Ectomycorrhizal spores are wind-blown and reinfestation of the soil may have occurred after fumigation.

Endomycorrhizal spores are soil-borne and typically are not transported by winds. Therefore a reduction in mycorrhizal colonization might occur more frequently among endomycorrhizal species than in pines. In one greenhouse study, chlamydospores of Glomus mosseae were added to soil prior to fumigation (O'Bannon and Nemec 1978). Soil was treated in sealed containers for four days. Eight months after treatment, no viable chlamydospores were found in either chloropicrin $\left(326 \mathrm{~kg} \mathrm{ha}^{-1}\right)$ or methyl bromide $\left(487 \mathrm{~kg} \mathrm{ha}^{-1}\right)$ treated soil. However, the weight of sour orange seedlings (Citrus aurantium L.) grown in chloropicrin treated soil $\left(7.9 \mathrm{~g}\right.$ seedling $\left.^{-1}\right)$ was as large as that from either the methyl bromide $(5.9 \mathrm{~g}$ seedling $\left.^{-1}\right)$ or nonfumigated soil $\left(6.5 \mathrm{~g} \mathrm{seedling}^{-1}\right)$. In contrast, a reduction in the percentage of mycorrhizal roots of rough lemon (Citrus jambhiri L.) resulted in a reduction in leaf area (Weir et al. 1980). Roots growing in chloropicrin treated soil (332 $\mathrm{kg} \mathrm{ha}^{-1}$ ) were $60 \%$ infected with mycorrhizae and roots in dazomet treated soil $\left(400 \mathrm{~kg} \mathrm{ha}^{-1}\right)$ were $36 \%$ infected (roots in nontreated soil were $96 \%$ infected). Foliar growth was slightly stunted with chloropicrin ( $17 \%$ reduction in shoot weight) and dazomet caused a $45 \%$ reduction.

Sewell et al. (1992) suggested the positive or negative effects of chloropicrin depend on soil phosphorus content. When soil phosphorus was low $(<20 \mathrm{ppm})$, the reduced incidence of vesicular-arbuscular mycorrhiza negatively affected apple seedling growth. However, after adding phosphorus to the soil, the seedlings exhibited a positive response to chloropicrin fumigation (even when mycorrhizal infection was reduced).

Hardwood seedbeds in the United States are often fumigated with a mixture of methyl bromide and chloropicrin. In one study in North Dakota (Riffle 1980), increasing the percentage of chloropicrin in a mixture with methyl bromide did not reduce endomycorrhizal development (when compared to $98 \%$ methyl bromide). Hardwood seedlings growing in soil treated with either (1) $98 \%$ methyl bromide at $384 \mathrm{~kg} \mathrm{ha}^{-1}$; or (2) $179 \mathrm{~kg} \mathrm{ha}^{-1}$ of chloropicrin plus $362 \mathrm{~kg} \mathrm{ha}^{-1}$ of methyl bromide; had $80 \%$ of their root segments colonized with endomycorrhiza. Seedlings growing in nonfumigated soil had $98 \%$ endomycorrhizal root segments.

\section{Effects on Trichoderma}

Fungi in the genus Trichoderma are considered to be beneficial for nursery seedlings (Mattis and Badanov 1973; Kelley 1976; Duda and Sierota 1987; Huang and Kuhlman 1991).
Table 3. Relative amount of chemical required to control soil pests (Adapted from Goring [1962] and Goring and Hamaker [1972]).

\begin{tabular}{lcccc}
\hline Fumigant & Nematodes & Fungi & Weed seed & Insects \\
\hline Chloropicrin & 4 & 5 & 12.5 & 1 \\
Methyl Bromide & 4 & 10 & 5 & 1 \\
1,3,-dichloropropene & 3 & 30 & 20 & 1.5 \\
\hline
\end{tabular}

Some Trichoderma species increase the speed of pine seed germination (Dong et al. 1987). One benefit from chloropicrin fumigation is an increase in Trichoderma soon after fumigation. This effect has been known for some time. In Ireland, the overall incidence of soil fungi was reduced with chloropicrin $\left(320 \mathrm{~kg} \mathrm{ha}^{-1}\right)$ but Trichoderma was increased. Roots growing in chloropicrin treated soil had two to six times the Trichoderma of those in untreated soil (McIlwaine and Malone 1976). In Belgium, fumigation with chloropicrin $\left(697 \mathrm{~kg} \mathrm{ha}^{-1}\right)$ resulted in a five-fold increase in Trichoderma at a soil depth of $20 \mathrm{~cm}$ (Welvaert 1974).

Assessments on the effect of soil fumigation on Trichoderma populations have been made in several studies in southern pine nurseries. In general, fumigation with either chloropicrin, or methyl bromide increases the population of Trichoderma soon after fumigation (Table 4). In some trials, fumigation with chloropicrin doubled the population of Trichoderma. In contrast, treating with dazomet tended to reduce numbers of Trichoderma. Similar findings were reported by Welvaert (1974).

\section{Effects of Using a Polyethylene Tarp}

Chloropicrin can be applied with or without a polyethylene tarp. Before 1970, most applicators did not use a plastic tarp although a few did (Brown 1985). The pesticide label suggests a higher rate may be required when no tarp is used. However, only a few trials in forest nurseries have examined the effects of tarping (Carey 1994). Possibly due to a limited amount of disease pressure, there was no appreciable effect of tarping at two southern pine nurseries. However, there was also no need for a tarp when applying chloropicrin to control a bacterial wilt of tomatoes (Enfinger et al. 1979). Since 100\% chloropicrin is applied as a liquid, the material remains in the soil longer than nontarped methyl bromide. The additional cost of applying a tarp might be offset somewhat by a reduction in chemical. For example, the cost of fumigation with a tarp might be $\$ 3,600 \mathrm{ha}^{-1}\left(200 \mathrm{~kg} \mathrm{ha}^{-1}\right)$ while no tarp might cost $\$ 3,000 \mathrm{ha}^{-1}$ $\left(250 \mathrm{~kg} \mathrm{ha}^{-1}\right)$. Chloropicrin is often applied without a tarp to soils for strawberries and other crops. For some crops, fumigation with chloropicrin without a tarp has been as effective in reducing root rot as methyl bromide applied under a tarp (Last and Cole 1969). 
Table 4. Percentage change (increase or decrease) in Trichoderma populations (relative to nontreated soil) for chloropicrin (100\%), methyl bromide and chloropicrin $(67 \%+33 \%)$ and dazomet.

\begin{tabular}{|c|c|c|c|c|c|c|}
\hline & \multicolumn{6}{|c|}{ State and year } \\
\hline & GA $^{1}-93$ & $\mathrm{SC}^{2}-93$ & GA-94 & MS $^{3}-94$ & $V^{4}{ }^{4}-94$ & GA-96 \\
\hline Chloropicrin & $+211 \% *$ & $-19 \% *$ & $+278^{*}$ & $+67 \% *$ & $+64 \%$ & $+95 \% *$ \\
\hline $\begin{array}{l}67 \% \text { methyl bromide and } \\
33 \% \text { chloropicrin. }\end{array}$ & $+268 \% *$ & $+55 \% *$ & - & $+59 \% *$ & $-24 \%$ & $+108 \% *$ \\
\hline Dazomet & $-91 \%$ & $-67 \% *$ & - & $-17 \%$ & $83 \%$ NR & - \\
\hline $\begin{array}{l}\text { Colonies per plate for } \\
\text { untreated soil }\end{array}$ & $(2.0)$ & $(30.5)$ & (3.4) & $(6.4)$ & $(7.5)$ & $(6.1)$ \\
\hline Days after treatment & 436 & 64 & 201 & 53 & 60 & 58 \\
\hline
\end{tabular}

$\mathrm{NR}=$ treatment not replicated

${ }^{1}$ Georgia.

${ }^{2}$ South Carolina.

${ }^{3}$ Mississippi.

${ }^{4}$ Virginia.

* $=$ Statistically different from nontreated soil

Table 5. The increase in plantable seedlings required to equal the cost of soil fumigation.

\begin{tabular}{|c|c|c|c|c|}
\hline $\begin{array}{l}\text { Seedling } \\
\text { value }\end{array}$ & $\begin{array}{l}\text { Fumigation } \\
\text { cost ha }\end{array}$ & $\begin{array}{c}\text { Additional } \\
\text { seedlings needed } \\
\text { ha }^{-1} \quad \mathrm{~m}^{-2}\end{array}$ & $\begin{array}{c}\% \text { increase in } \\
\text { conifer stand } \\
(1.5 \text { million base })\end{array}$ & $\begin{array}{c}\% \text { increase in } \\
\text { hardwood stand } \\
(0.5 \text { million base) }\end{array}$ \\
\hline$\$ 0.03$ & $\$ 3,600$ & 120,000 & $8 \%$ & $24 \%$ \\
\hline$\$ 0.06$ & $\$ 3,600$ & 60,000 & $4 \%$ & $12 \%$ \\
\hline$\$ 0.12$ & $\$ 3,600$ & 30,000 & $2 \%$ & $6 \%$ \\
\hline$\$ 0.18$ & $\$ 3,600$ & 20,000 & $1.3 \%$ & $4 \%$ \\
\hline$\$ 0.36$ & $\$ 3,600$ & 10,000 & $0.7 \%$ & $2 \%$ \\
\hline
\end{tabular}

\section{Economics of Fumigation with Chloropicrin}

The motivation for soil fumigation can be looked at from either a financial or pathological perspective (van Assche 1974). From a financial perspective, as crop value increases, the motivation for soil fumigation increases. This helps explain why chloropicrin is used more for the production of strawberries than for either corn or soybeans. Likewise, the final decision regarding fumigation will depend on whether seedlings are valued at either $\$ 0.03$ or $\$ 0.18$ each. At many nurseries, only the cost of production is considered. However, with some companies, seedlings are assessed a higher value due to a consideration of the net present value of the seedlings with respect to timber production. In other words, genetically improved stock (South 1987) and morphologically improved seedlings (South 1993) have a higher net present value than unimproved seedlings. In some situations, the net present value may be six times higher than the cost of production. Rarely are these values considered when determining the benefit/cost ratio for soil fumigation.

Decision models can be developed to assist growers in determining the economic threshold level for soil fumigation (Bailey and Matyac 1989). An example (Table 5) illustrates how many additional seedlings need to be gained to justify an investment of $\$ 3,600 \mathrm{ha}^{-1}$ (assuming a hectare of nonfumigated seedbed will produce either 1.5 million conifer seedlings or 0.5 million hardwood seedlings). A gain of only 20,000 plantable seedlings ha $\mathrm{h}^{-1}$ is needed when seedlings are valued at $\$ 0.18$ each. This would be about a $1.3 \%$ increase in seedling production for pine seedbeds or a $4 \%$ increase for hardwoods.

Several nurseries have been permanently closed as a result of soil-borne disease (Brown 1985; Juzwik et al. 1988). When virulent soilborne pathogens are present, chemical fumigation can sometimes double seedling production (Sutherland and Adams 1965; Agnihotri 1971; Enebak et al. 1990). With this level of production increase, fumigation is easily justified. Fumigation with chloropicrin in Wisconsin increased crop value by at least $\$ 30,000 / \mathrm{ha}$ (assuming a value of $\$ 0.15$ plantable seedling ${ }^{-1}$ ). However, recently in southern pine nurseries soilborne diseases have seldom been epidemic and therefore dramatic increases in seedling production of the magnitude illustrated (Table 1) are now rare. Therefore, soil is fumigated about once every four years. At these nurseries, the cost of fumigation is spread over two (sometimes three) seedling crops. The required increase in seedling production (Table 5) need not occur just during the first year after treatment. For example, at $\$ 0.06$ per conifer seedling, fumigation could be justified if the crop production was increased by $3 \%$ the first year and $1 \%$ the second year.

In order to maintain a good reputation, some nursery managers will cite disease prevention as the motive for soil fumigation. The use of chloropicrin might affect the number of disease free seedlings but may not affect the number of plantable seedlings. For example, the number of "plantable" slash pine seedlings was not increased by chloropicrin (Table 1) but the number of "healthy" seedlings was doubled. If both diseased and healthy seedlings are valued the same, then some might say there was no need to fumigate. However, if two nurseries are competing for seedling sales, the nursery that consistently produces disease free seedlings will have an advantage over nurseries that produce plantable diseased seedlings once or twice a decade. The old philosophy of "here are the seedlings, you can either take them or leave them" is no longer valid if healthy seedlings can be purchased from competing nurseries that routinely practice soil fumigation.

In their economic analysis of soil fumigation, some pathologists do not include costs which can occur from reduced outplanting survival. At some nurseries, diseased seedlings that appear healthy will exhibit lower outplanting survival than healthy seedlings (Saunders et al. 1992; Barnard et al. 1985; Barnard 
1994). However, in a totally integrated pest management system, nursery managers should strive to avoid producing asymptomatic, diseased seedlings. This goal can be accomplished by either prevention (e.g. judicious use of soil fumigation) or by culling a large number of asymptomatic seedlings. One problem with culling asymptomatic diseased seedlings is that healthy seedlings will also be discarded. To avoid a "threat" of nursery-to-field carryover of a pathogen, some pathologists do not recommend soil fumigation. Some suggest not sowing pathogen infected seedbeds (Sutherland 1984) or skipping beds with disease during lifting. However, the elimination of entire seedbeds is not a desirable choice in years when the demand for seedlings far exceeds the supply.

\section{Conclusions}

If production of methyl bromide ceases in the United States, many managers of bare-root nurseries will need to adjust their pest management programs. Those that adopt the practice of fumigating with chloropicrin may experience an easy transition since its suppression of pathogens and nematodes appear to be similar to methyl bromide. Some managers may select chloropicrin as their preferred fumigant due to the residual "biocontrol effect". This fumigant often increases soil populations of Trichoderma which can remain elevated for several months after fumigation. However, managers that have been relying on methyl bromide for weed control may need to sharpen their weed management skills. Some managers may choose to increase the use of selective herbicides.

\section{References}

Agnihotri, V.P. 1971. Effects of certain fungitoxicants on the viability and pathogenicity of Sclerotia of Waitea circinata. Phytopathol. Z. 70: 71-80.

Aldhous, J.R. 1972. Nursery practice. Forestry Commission Bulletin \#43. Her Majesty=s Stationery Office, London. 184 p.

Bailey, J.E. and C.A. Matyac. 1989. A decision model for use of fumigation and resistance to control Cylindrocladium black rot of peanuts. Plant Dis. 73: 323-326.

Barnard, E.L. 1994. Nursery-to-field carryover and post-outplanting impact of Macrophomina phaseolina on loblolly pine on a cutover forest site in North Central Florida. Tree Planters' Notes 45: 68-71.

Barnard, E.L., R.S. Webb, S.P. Gilly, and W.D. Lante. 1985. Phytophthora cinnamomi infection in sand pine seedlings in Florida nurseries and effects on outplant. pp 486-495 In Proc. International Symposium on Nursery Management Practices for the Southern Pines. D.B. South (ed.). Montgomery, Alabama August 4-9. School of Forestry and Alabama Agricultural Experiment Station.

Bassett, C. and G.M. Will. 1964. Soil sterilisation trials in two forest nurseries. N.Z. J. For. 9: 50-58.

Benzian, B. 1959. Nutrition problems in forest nurseries. J. Sci. Food Agric. 10: 637-644.

Benzian, B. 1965. Experiments on nutrition problems in forest nurseries. (Vol. 1) Forestry Commission Bull. 37. H.M.S.O London $251 \mathrm{p}$.

Breakey, E.P., C. J. Gould and C.E. Reynolds. 1945. Seed-corn maggots as pests of coniferous seedlings in western Washington. J. Econ. Entomol. 38: 121.

Brown, B.N. 1985. Phytophthora cinnamomi root rot in Pinus nurseries soil fumigation and disease prevention by hygiene. pp. 507-514 In Proc. International Symposium on Nursery Management Practices for the Southern Pines. D.B. South (ed.). Montgomery, Alabama August 4-9. School of Forestry and Alabama Agricultural Experiment Station.
Carey, W.A. 1994. Chemical alternatives to methyl bromide. pp. 4-11 In Proc. Forest and Conservation Nursery Associations. T.D. Landis and R.K. Dumroese (Tech. Coordinators). USDA Forest Service General Technical Report RM-GTR-257.

Coz, R.S. 1951. A preliminary report on etiological and control studies of damping-off and root-rot in the conifer seedbed in Delaware. Plant Dis. Rep. 35: 374-378.

Dong, L.F., X.Y. Zhang and H.G. Zhang. 1987. Breaking seed dormancy of Pinus bungeana Zucc. with Trichoderma-4030 inoculations. New-Forests 1: 245-249.

Duda, B. And Z.H. Sierota. 1987. Survival of Scots pine seedlings after biological and chemical control of damping-off in plastic greenhouses. Eur. J. For. Pathol. 17: 110-117.

Enebak, S.A., M.A. Palmer and R. A. Blanchette. 1990. Managing soilborne pathogens of white pine in a forest nursery. Plant Dis. 74: 195-198.

Enfinger, J.M., S.M McCarter and C.A. Jaworski. 1979. Evaluation of chemicals and application methods for control of bacterial wilt Pseudomonas solanacearum of tomato transplants. Phytopathology 69: 637-640.

Goring, C.A.I. 1962. Theory and principles of soil fumigation. Adv. Pest Contr. Res. 5: 47-84.

Goring, C.A.I. and J.W. Hamaker. 1972. Organic chemicals in the soil environment. Vol 2. Marcel Dekker, Inc., New York. 968 p.

Harris, D.C. 1991. A comparison of dazomet, chloropicrin and methyl bromide as soil disinfectants for strawberries. J. Hortic. Sci. 66: 51-58. Hipps, N.A., K.H. Higgs and L.G. Collard. 1997. Effects of root wrenching and irrigation rate on the growth and water relations of Castanea sativa and Quercus robur seedlings in the nursery and after outplanting. Can. J. For. Res. 27: 180-188.

Huang, J.W. and E.G. Kuhlman. 1991. Mechanisms inhibiting damping-off pathogens of slash pine seedlings with a formulated soil amendment. Phytopathology 81: 171-177.

Jackson, K.E. 1934. Chloropicrin. Chem. Review 14: 251-286.

Juzwik, J., C. Honhart and N. Chong. 1988. Cylindrocladium root rot in Ontario bare-root nurseries: estimate of spruce seedling losses. Can. J. For. Res. 18: 1493-1496.

Kelley, W.D. 1976. Evaluation of Trichoderma harzianum-impregnated clay granules as a biocontrol for Phytophthora cinnamomi causing damping-off of pine seedlings. Phytopathology 66: 1023-1027. Koch, B.L. R.P. Covey, Jr. and W.A. Haglund. 1980. Growth response of apple and pear seedling to pear soil fumigation with chloropicrin. HortScience 15: 598-600.

Last, F.T. and J.S. Cole. 1969. Comparisons of methyl bromide fumigation with other ways of minimizing the incidence of tomato brown root rot. Plant Pathol. 18: 145-151.

Lindgren, R.M. and B.W. Henry. 1949. Promising treatments for controlling root disease and weeds in a southern pine nursery. Plant Dis. Rep. 33(5): 228-231.

Mai, W.F. and G.S. Abawi. 1978. Determining the cause and extent of apple, cherry, and pear replant diseases under controlled conditions. Phytopathology 68: 1540-1544.

Mattis, G.Ya and A.P. Badanov. 1973. Biological method of control of Fusarium on seedlings. Lesnoe-Khozyaistvo. 9: 58-60.

McIlwaine, R.S. and J.P. Malone. 1976. Effects of chloropicrin soil treatment on the microflora of soil and ryegrass roots and ryegrass yield. Trans. Br. Mycol. Soc. 67: 113-120.

McNabb, K., D.B. South and R.J. Mitchell. 1995. Weed management systems for forest nurseries and woodlands. pp. 667-710 (Chapter 16). In Handbook for weed management systems. A.E. Smith (ed.). Marcel Dekker, Inc., New York.

O'Bannon, J.H. and S. Nemec. 1978. Influence of soil pesticides on vesicular-arbuscular mycorrhizae in a citrus soil. Nematropica 8(2): 56-61.

Pouwer, A. and H.H. van Doesburg. 1967. Grondontsmetting in de boomkwekerij of kleigrond. pp. 86-88 In Jaarboek Proefstation voor de Boomkwekerij te Boskoop. 
Riffle, J.W. 1980. Growth and endomycorrhizal development of broadleaf seedling in fumigated nursery soil. For. Sci. 26: 403-413. Ruhm, W. 1959. Nematoden und Forstpflanzen. I. Mitteilung. Zur Bodenentseuchung in Forstbaumschulen und Forstkamps. Merck-Blatter 9(3): 1-16.

Sassaman, J.F., M.M. Jacobs, P.H. Chin, S. Hsia, R.J. Pienta and J.M Kelley. 1986. Pesticide background statements; Volume II. Fungicides and fumigants. USDA Forest Service Agriculture Handbook \#661.

Saunders, J.E., J. Juzwik and R. Hutchison. 1992. Outplanting survival of Cylindrocladium root rot affected black spruce. Can. J. For. Res. 22: 1204-1207.

Sewell, G.W.F., A.L. Roberts and R.F. Elsey. 1992. Apple replant disease: the assessment and results of seedling bio-assays of growth responses to soil fumigation with chloropicrin. Ann. Appl. Biol. 121: 199-209.

South, D.B. 1977. Artificial inoculation of fumigated nursery beds with endomycorrhizae. Tree Planters' Notes 28(3,4): 3-6.

South, D.B. 1987. Economic aspects of nursery seed efficiency. South. J. Appl. For. 11(2): 106-109.

South, D.B. 1993. Rationale for growing southern pine seedlings at low seedbed densities. New Forests 7: 63-92.

South, D.B. 1995. Contrasting weed management systems in bareroot conifer nurseries. For. Chron. 71: 331-342.

Stark, Jr. F.L. 1948. Investigations of chloropicrin as a soil fumigant. Cornell University Agricultural Experiment Station Memoir 278. $61 \mathrm{p}$.

Stevens, T.S. 1997. The use of chemical fumigants and potential alternatives at Weyerhaeuser Mima Nursery. pp. 144-149 In National Proceedings, Forest and Conservation Nursery Associations. T.D. Landis and D.B. South. (Tech. Coords.) Gen. Tech. Rep. PNW-GTR-389. USDA Forest Service, Portland, OR. 282 p.

Sutherland, J.R. and R.E. Adams. 1965. Stand, growth, and nitrogen content of red pine seedlings following chemical treatment of the soil to control disease. Tree Planters' Notes 73: 7-10.

Sutherland, J.R. 1984. Pest Management in northwest bareroot nurseries. Chapter 19 In Forest nursery manual: Production of bareroot seedlings. M. L. Duryea and T.D. Landis (eds.). Martinus Nijhoff/Dr W. Junk Publishers The Hague/Boston/Lancaster. For Forest Research Laboratory, Oregon State University. Corvallis. pp. 203-210.
Terashita, T. 1962. Studies on the disease of Acacia dealbata. I. Isolation of pathogens and some aspects of their overwintering. II. Control of the seedling diseases by chemicals. Ringydo Shikenjdo kenkydu hdokoku 147: 119-136.

Thulin, I.J., G.M. Will and C. Bassett. 1958. A pilot trial of soil sterilisation in a forest nursery. N.Z. J. For. 7(5): 88-93.

Van Assche, C. 1974. Purpose, control and motivation of a chemical soil disinfestation. Agro-Ecosystems 1: 107-116.

Van den Driessche. R. 1963a. Nursery experiments with Douglas fir. Commonwealth For. Rev. 42(3): 242-254.

Van den Driessche. R. 1963b. Partial sterilization of Douglas-fir seedbeds with formalin and chloropicrin. For. Sci. 9: 330-334.

Van den Driessche. R. 1968. The desirability of micronutrient amendments for conifer nurseries. BC Forest Serv. Res. Rev. 1968: 50-52.

Van den Driessche, R. 1969. Forest nursery handbook. BC Forest Service. Research Note \#48. 44 p.

Welvaert, W. 1974. Evolution of the fungus flora following different soil treatments. Agro-Ecosystems 1: 157-168.

White, D.P. and H.S. Potter. 1963. Soil treatments for control of pathogens and weeds in the greenhouse and nursery production of pine seedlings. Quart. Bull. Mich. Agric. Exp. Sta. 45(4): 612-617. Weir, R.G., D.B. Letham, P. Broadbent and P.J. Nicholls. 1980. The effect of phosphorus and vesicular-arbuscular mycorrhizal development on growth of citrus in a Sandmount series soil. pp. 288-292 In Proceedings of the International Society of Citriculture 1978. Griffith, NSW, Australia

Will, G.M. 1962. The uptake of nutrients from sterilised forest-nursery soils. N.Z. J. Agric. Res. 5: 425-432.

Will, G.M. and C. Bassett. 1959. Soil sterilisation trials in seven forest nurseries. N.Z. J. For. 8(4): 587-593. 